\title{
Variation in stable carbon and oxygen isotopes of individual benthic foraminifera: tracers for quantifying the magnitude of isotopic disequilibrium
}

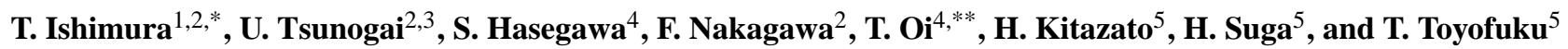 \\ ${ }^{1}$ Geological Survey of Japan, National Institute of Advanced Industrial Science and Technology (AIST), Tsukuba, Japan \\ ${ }^{2}$ Division of Earth and Planetary Sciences, Graduate School of Science, Hokkaido University, Sapporo, Japan \\ ${ }^{3}$ Graduate School of Environmental Studies, Nagoya University, Nagoya, Japan \\ ${ }^{4}$ Graduate School of Science and Technology, Kumamoto University, Kumamoto, Japan \\ ${ }^{5}$ Institute of Biogeosciences, Japan Agency for Marine-Earth Science and Technology, Yokosuka, Japan \\ * currently at: Department of Chemistry and Material Engineering, Ibaraki National College of Technology, \\ Hitachinaka, Japan \\ ** currently at: Department of Earth and Planetary Science, University of Tokyo, Tokyo, Japan
}

Correspondence to: T. Ishimura (toyoho.ishimura@gmail.com)

Received: 8 May 2012 - Published in Biogeosciences Discuss.: 31 May 2012

Revised: 22 September 2012 - Accepted: 2 October 2012 - Published: 8 November 2012

\begin{abstract}
Stable carbon and oxygen isotopic compositions $\left(\delta^{13} \mathrm{C}\right.$ and $\left.\delta^{18} \mathrm{O}\right)$ of benthic foraminiferal carbonate shells have been used to reconstruct past bottom-water environments. However, the details of factors controlling the isotopic disequilibrium between the shells and the surrounding bottom seawater (so-called the "vital effect") are still ambiguous. In this study, we analyzed the isotopic composition of individual benthic foraminifera of multiple species by using a customized high-precision analytical system, and found that the magnitude of the isotopic disequilibrium between benthic foraminiferal shell and the surrounding bottom seawater $\left(\delta^{13} \mathrm{C}_{\mathrm{DIC}}\right.$ and $\left.\delta^{18} \mathrm{O}_{\text {water }}\right)$ in different species is correlated with inter-individual isotopic variations. As a result, we can choose suitable species as bottom-water proxies by using the inter-individual isotopic variations. In addition, by using the simplified interpretation of the inter-individual and inter-species isotopic variations established in this study, we could reconstruct the $\delta^{13} \mathrm{C}$ values of dissolved inorganic carbon in bottom water by correcting foraminiferal isotopic compositions for the isotopic shift resulting from the isotopic effects (vital effect, microhabitat effect, and many other reported isotopic effects). Our findings will allow the use of isotope data for benthic foraminifera as more reliable proxies
\end{abstract}

for reconstructing past bottom-water conditions and evaluating global carbon cycling.

\section{Introduction}

Variations in the stable carbon and oxygen isotopic composition $\left(\delta^{13} \mathrm{C}\right.$ and $\delta^{18} \mathrm{O}$ ) of foraminiferal carbonate shells have been used for over half a century to estimate paleoenvironmental parameters such as temperature, to quantify global changes in sea level and deep-sea circulation, and to document events such as large seafloor methane releases (e.g. Emiliani, 1955; Shackleton and Opdyke, 1973; Kennett et al., 2000; Zachos et al., 2001). In particular, $\delta^{13} \mathrm{C}$ and $\delta^{18} \mathrm{O}$ of benthic foraminiferal shells have been used as tracers to reconstruct past bottom-water environments. However, there is still ambiguity concerning the factors controlling the isotopic disequilibrium between the isotopic compositions $\left(\delta^{13} \mathrm{C}\right.$ and $\delta^{18} \mathrm{O}$ ) of benthic foraminifera and the environmental factors $\left(\delta^{13} \mathrm{C}\right.$ of dissolved inorganic carbon (DIC) and $\delta^{18} \mathrm{O}$ of seawater) (Grossman, 1987; McCorkle et al., 1990; Spero et al., 1997; Zeebe et al., 1999; Bijma et al., 1999; Erez, 2003; Schmiedl et al., 2004). 
Major isotopic variations in some species of benthic foraminifera are utilized as paleoindicators of bottom-water conditions, but recently researchers have begun to quantify in detail the relationship between the isotopic composition of benthic foraminifera and environmental factors (e.g. Rathburn et al., 1996; McCorkle et al., 1997; Rathburn et al., 2003; Mackensen and Licari, 2004; Martin et al., 2004; Schmiedl et al., 2004; Fontanier et al., 2006; McCorkle et al., 2008). Precise calibration and validation of isotopic indicators in benthic foraminifera will broaden the range of their application as paleoenvironmental tracers. However, two problems in using the isotopic evidence in foraminiferal shells have limited their range of application and the material available for use.

First, until recently it was not possible to analyze the stable isotopic compositions of carbonate samples smaller than about $20 \mu \mathrm{g}$ (Revesz and Landwehr, 2002; Ishimura et al., 2004; de Groot, 2008; Velivetskaya et al., 2009) and obtain results with an acceptable error range; thus, each sample analyzed included multiple individuals, resulting in isotopic values averaged across individuals. Among thousands of calcareous foraminifera, the reported isotopic data of individual foraminiferal shells in previous studies are limited to the taxa that have large and thick $\mathrm{CaCO}_{3}$ shells (e.g. Rathburn et al., 2003; Uchida et al., 2008; Martin et al., 2010; Bernhard et al., 2010a). Therefore, it was difficult to obtain data from sites with only foraminifera of small size or rare occurrence, for example, the deep sea or the high latitudes.

Second, although the isotopic composition of biogenic carbonate is primarily determined by water temperature, $\delta^{18} \mathrm{O}$ of water, and $\delta^{13} \mathrm{C}$ of DIC, the $\delta^{13} \mathrm{C}$ and $\delta^{18} \mathrm{O}$ values of deep-sea benthic foraminifera are known to deviate widely from equilibrium with seawater (Grossman, 1987; Rathburn et al., 1996; McCorkle et al., 1997; Fontanier et al., 2006; Mackensen and Licari, 2004), a variation generally known as the "vital effect". Possible causes of isotopic disequilibrium include respiration, ontogenetic effects, microhabitats, or carbonate ion concentrations, and many other factors have been suggested in previous studies (Rohling and Cooke, 1999; Mackensen, 2008). The complex interactions between these factors and the isotopic composition of biogenic calcite make it difficult to discuss them separately, or to know the original values in calcite at equilibrium with bottom water. To reduce this "isotopic noise", isotopic analyses in the past had to include several individual foraminifera. However, such average isotopic values do not always indicate the absolute isotopic values at equilibrium with ambient water (e.g. Grossman, 1987), and the details of the isotopic variations of whole benthic foraminifera are not well known. In other words, we could not see the whole image of characteristics of the isotopic disequilibrium of the benthic foraminifera. The stable isotopes in foraminifera could be more effectively used as environmental proxies, for example for modeling global carbon cycling, with a clearer understanding of the characteristics of their isotopic disequi-

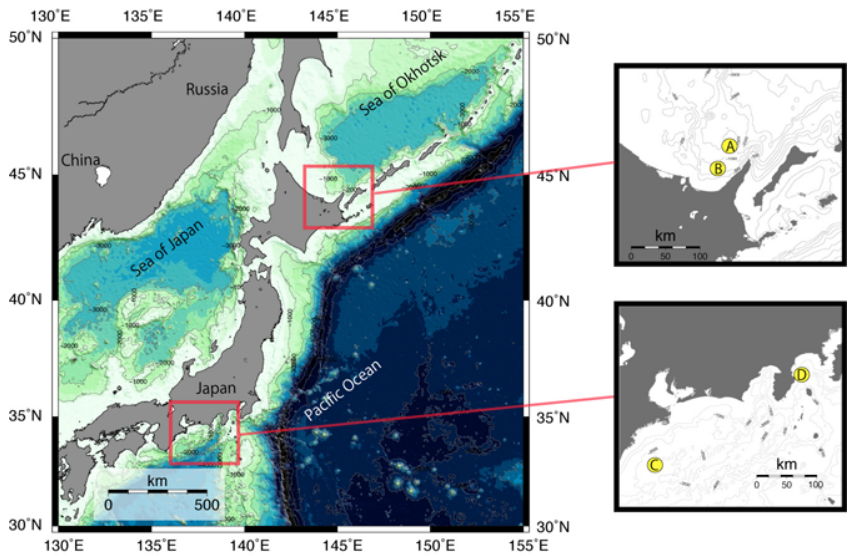

Fig. 1. Map of the study area and sampling sites. Site A $\left(44^{\circ} 10^{\prime} \mathrm{N}\right.$, $144^{\circ} 45^{\prime} \mathrm{E}$; water depth $\left.870 \mathrm{~m}\right)$ and site B $\left(44^{\circ} 31^{\prime} \mathrm{N}, 145^{\circ} 00^{\prime} \mathrm{E}\right.$; water depth $1208 \mathrm{~m})$, Sea of Okhotsk off Abashiri; site C $\left(33^{\circ} 42^{\prime} \mathrm{N}\right.$, $137^{\circ} 05^{\prime} \mathrm{E}$; water depth $\left.1881 \mathrm{~m}\right)$, Nankai Trough off Kumano; site $\mathrm{D}\left(35^{\circ} 00^{\prime} \mathrm{N}, 139^{\circ} 14^{\prime} \mathrm{E}\right.$; water depth $\left.1182 \mathrm{~m}\right)$, Sagami Bay.

librium. In this study, we analyzed the $\delta^{13} \mathrm{C}$ and $\delta^{18} \mathrm{O}$ of individual shells of deep-sea benthic foraminifera in coretop samples from four sites in continental margin of the northwestern Pacific Ocean to characterize the magnitude of inter-individual isotopic variations by using a custom-made high-precision isotope analysis system (Ishimura et al., 2004, 2008). The quantity required by their system is less than $1 / 100$ of that required by conventional analytical methods. Furthermore, the use this technique allows inter-individual and inter-species variability in recorded stable isotope signatures to be determined. We expect the results to be useful for exploring which species are most appropriate to use as paleoindicators in paleoenvironmental studies.

\section{Materials and methods}

\subsection{Foraminifer and water samples}

Surface sediment samples were collected with multicorers from two stations close to each other on the same continental slope in the southwestern Sea of Okhotsk off Abashiri, Hokkaido Island, Japan. Samples were collected from a water depth of $870 \mathrm{~m}$ at $44^{\circ} 10^{\prime} \mathrm{N}, 144^{\circ} 45^{\prime} \mathrm{E}$ during cruise HO76 of R/V Hokusei (Hokkaido University, Japan) in September 1997 and from $1208 \mathrm{~m}$ at $44^{\circ} 31^{\prime} \mathrm{N}, 145^{\circ} 00^{\prime} \mathrm{E}$ during cruise MR06-04 of R/V Mirai (Japan Agency for MarineEarth Science and Technology (JAMSTEC)) in October 2006 (Fig. 1).

The top layer of the surface sediment $(0-10 \mathrm{~cm}$ below the seafloor) was subsampled every centimeter and used to determine inter-individual isotopic variation for each foraminiferal species selected for study. The sediment was stained with $0.5 \%$ Rose Bengal solution for at least one week to distinguish living (Rose Bengal stained) foraminifera from 


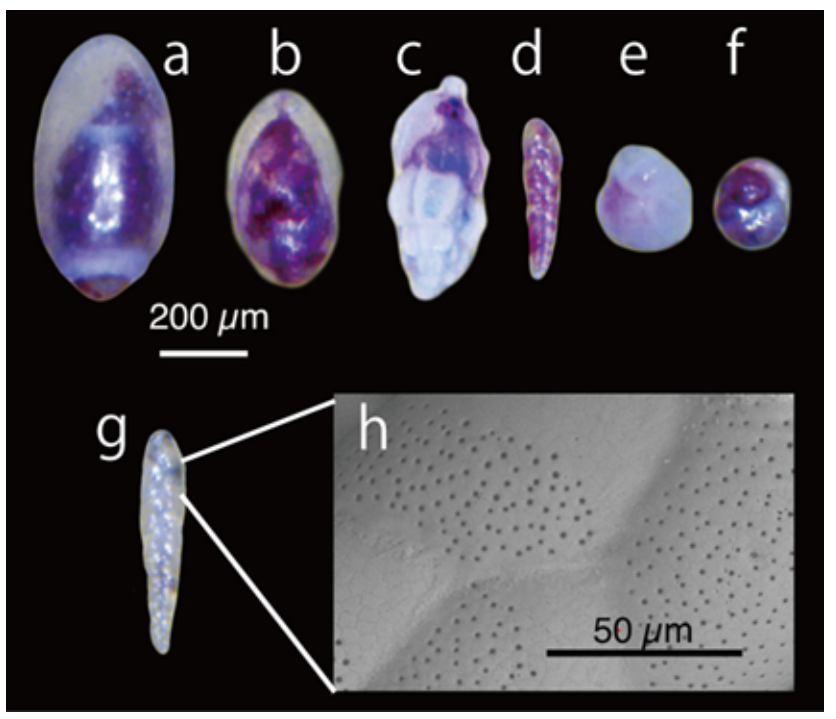

Fig. 2. Photomicrographs of Rose Bengal-stained specimens of analyzed foraminifera (a-g). (a) Chilostomella ovoidea, (b) Globobulimina auriculata, (c) Uvigerina akitaensis, (d) Brizalina pacifica, (e) Islandiella norcrossi, (f) Takayanagia delicata, (g) dead B. pacifica. (h) Scanning electron micrograph of B. pacifica.

dead (not stained) (Fig. 2). We did not use ethanol and formaldehyde but filtered seawater for the Rose Bengal solution. Previous studies reported that Rose Bengal staining method does not allow accurate identification of living individuals (e.g. Bernhard, 1988; Bernhard et al., 2006). However, during the isotopic analytical procedures of stained individuals in this study, we observed that foraminiferal soft tissues remained completely in the reaction tubes after the acid reaction of the calcite shell. Therefore, we considered the stained individuals as living. Note that our analytical method (Ishimura et al., 2004) allows us to observe the entire reaction process under a microscope. The samples were then washed in a $63-\mu \mathrm{m}$-mesh sieve with $50^{\circ} \mathrm{C}$ water. The sediment retained in the sieve was oven-dried at $40^{\circ} \mathrm{C}$, and individual foraminifera were picked out for isotopic analysis.

The dominant species in these samples were the hyaline calcareous benthic foraminifera of the Cassidulina group (Cassidulina norvangi, Islandiella norcrossi, Takayanagia delicata), Brizalina pacifica, and Stainforthia loeblichi (Fig. 3). We analyzed the $\delta^{13} \mathrm{C}$ and $\delta^{18} \mathrm{O}$ values of the benthic foraminifera C. norvangi, B. pacifica, and S. loeblichi from the 870-m samples, and Uvigerina akitaensis, I. norcrossi, T. delicata, Chilostomella ovoidea, Globobulimina auriculata, and B. pacifica from the 1208-m samples (Fig. 3). All specimens used for isotopic measurements were examined under a stereomicroscope and confirmed to have transparent calcite shells with no authigenic carbonate (Fig. 2). We cleaned all individual foraminifera with Milli-Q water before isotopic analysis, and we did not find any dissolution and remineralization in our analyzed samples.

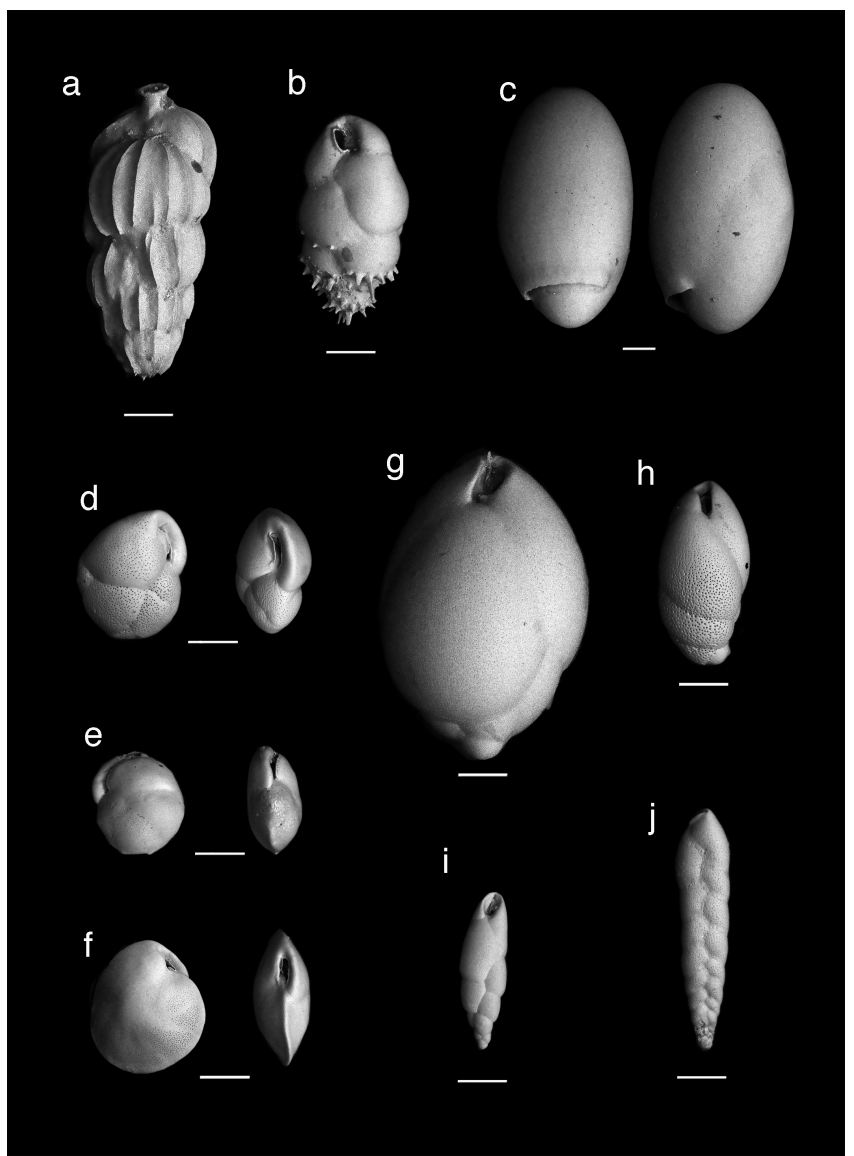

Fig. 3. Scanning electron microscope images of studied species. (a) Uvigerina akitaensis, (b) Bulimina aculeata, (c) Chilostomella ovoidea, (d) Cassidulina norvangi, (e) Takayanagia delicata, (f) Islandiella norcrossi, (g) Globobulimina auriculata, (h) Rutherfordoides cornuta, (i) Stainforthia loeblichi, and (j) Brizalina pacifica. Scale bars represent $100 \mu \mathrm{m}$. (a), (c), (d), (e), (f), (i) and (j); Sea of Okhotsk; (b), Nankai Trough; (g) and (h), Sagami Bay.

Water samples were also collected from the 1208 -m waterdepth site where foraminiferal samples were collected during cruise MR06-04 of the R/V Mirai in August 2006 (Table 1). Pore-water samples were squeezed from sediments that had been collected with a 50-cm-long multicorer, at depth intervals of $0,1-3,4-6$, and $7-9 \mathrm{~cm}$ below the sea floor. Watercolumn samples were collected using Niskin bottles mounted on a conductivity-temperature-depth (CTD) rosette sampler and used for isotopic analysis.

For comparison with our samples, we also determined the $\delta^{13} \mathrm{C}$ and $\delta^{18} \mathrm{O}$ values of Bulimina aculeata (Fig. 3) in surface sediment from the Nankai Trough $\left(33^{\circ} 42^{\prime} \mathrm{N}, 137^{\circ} 05^{\prime} \mathrm{E}\right.$; water depth 1881 m, Fig. 1) off Kumano, Japan, collected with a push corer by the submersible Shinkai6500 during cruise YK02-02 of R/V Yokosuka (JAMSTEC) in May 2002. This species has been used previously for the isotopic reconstruction of paleoenvironments (Oba, 1988; McCorkle et al., 1997; Mackensen and Licari, 2004). The sediment 
sample from 0 to $7 \mathrm{~cm}$ below the sea floor was used for pore-water analysis and foraminiferal examination and then treated in the same manner as the samples from the Okhotsk Sea for analysis of the stable isotopes of individual shells. We also determined the $\delta^{13} \mathrm{C}$ and $\delta^{18} \mathrm{O}$ values of $G$. auriculata, C. ovoidea, and Rutherfordoides cornuta (Fig. 3) in the upper $2 \mathrm{~cm}$ of sediment collected with a push corer from Sagami Bay $\left(35^{\circ} 00^{\prime} \mathrm{N}, 139^{\circ} 14^{\prime} \mathrm{E}\right.$; water depth $\left.1182 \mathrm{~m}\right)$ during cruise KT05-18 of R/V Tansei (JAMSTEC) in August 2005.

\subsection{Stable carbon and oxygen isotope analysis}

We used a continuous-flow isotope ratio mass spectrometry analytical system (Ishimura et al., 2004, 2008) to determine $\delta^{13} \mathrm{C}$ and $\delta^{18} \mathrm{O}$ of individual foraminifera. This system allowed us to determine $\delta^{13} \mathrm{C}$ and $\delta^{18} \mathrm{O}$ of as little as $0.2 \mu \mathrm{g} \mathrm{CaCO}$ with a long-term external precision of better than $\pm 0.10 \%$ or $\delta^{13} \mathrm{C}$ and $\pm 0.14 \%$ o for $\delta^{18} \mathrm{O}$. This system can be used for high-precision stable isotope measurements of all foraminifera, including even the smallest species (Kimoto et al., 2009). Isotopic values are reported relative to the Vienna Peedee belemnite (VPDB) standard. In addition to determining stable isotopes in both living (Rose Bengal stained) and dead individual foraminifera, we also determined the stable isotopic compositions of samples composed of five individuals of $C$. norvangi, B. pacifica, or $S$. loeblichi for comparison. We also include here the analytical results from a previous study (Ishimura et al., 2004) for C. norvangi (reported as Globocassidulina sp.). The mass of calcite in foraminiferal shells was calculated from the volume of $\mathrm{CO}_{2}$ gas evolved during their reaction with phosphoric acid (Ishimura et al., 2004).

The $\delta^{13} \mathrm{C}$ values of dissolved inorganic carbon (DIC) in water were determined by the method presented in Miyajima et al. (1995). The $\delta^{18} \mathrm{O}$ in water samples was analyzed by using a wavelength-scanned cavity ring-down spectroscopy isotopic water analyzer (L2120-i; Picarro Inc., Santa Clara, CA, USA) at Hokkaido University. Analytical errors of these methods are within $\pm 0.1 \%$ of $\delta^{13} \mathrm{C}$ and $\pm 0.2 \%$ ofor $\delta^{18} \mathrm{O}$. $\delta^{18} \mathrm{O}$ values of water samples are reported relative to Vienna Standard Mean Ocean Water (VSMOW).

\subsection{Calculation of isotopic differences between foraminiferal shells and bottom water $(\Delta \delta 13 \mathrm{C}$ and $\Delta \delta 180)$}

In this study, the stable isotopic compositions of foraminiferal shells are discussed as $\Delta \delta^{13} \mathrm{C}$ and $\Delta \delta^{18} \mathrm{O}$. $\Delta \delta^{13} \mathrm{C}$ is the difference between the $\delta^{13} \mathrm{C}$ of foraminiferal shell and the $\delta^{13} \mathrm{C}_{\mathrm{DIC}}$ of bottom water; $\Delta \delta^{18} \mathrm{O}$ is the difference between the $\delta^{18} \mathrm{O}$ of foraminiferal shell and calcite in equilibrium with bottom-water conditions $\left(\delta^{18} \mathrm{O}_{\text {e.c. }}\right)$, as discussed in previous studies (McCorkle et al., 1990; Rathburn et al., 1996; McCorkle et al., 1997; Schmiedl et
Table 1. $\delta^{13} \mathrm{C}$ of dissolved inorganic carbon, $\delta^{18} \mathrm{O}$ of water samples, and water temperature in the study area. Sediment intervals are $\pm 0.5 \mathrm{~cm}$. Bottom water samples are collected with multicorers.

\begin{tabular}{|c|c|c|c|}
\hline Site & \multicolumn{3}{|c|}{$\begin{array}{c}\text { Sea of Okhotsk (MR06-4 St.4) } \\
\left(44^{\circ} 31^{\prime} \mathrm{N}, 145^{\circ} 00^{\prime} \mathrm{E}\right)\end{array}$} \\
\hline Water depth & $1208 \mathrm{~m}$ & & \\
\hline $\begin{array}{l}\text { Water depth } \\
\text { (m) }\end{array}$ & $\begin{array}{r}10^{3} \times \delta^{13} \mathrm{C} \\
(\mathrm{VPDB})\end{array}$ & $\begin{array}{r}10^{3} \times \delta^{18} \mathrm{O} \\
(\mathrm{VSMOW})\end{array}$ & $\begin{array}{r}\text { Temperature } \\
\left({ }^{\circ} \mathrm{C}\right)\end{array}$ \\
\hline 30 & +0.9 & -0.7 & - \\
\hline 50 & +1.0 & -0.6 & - \\
\hline 75 & +0.8 & -0.6 & - \\
\hline 100 & +0.9 & -0.6 & - \\
\hline 200 & +0.9 & -0.6 & - \\
\hline 300 & +0.6 & -0.6 & - \\
\hline 500 & -0.5 & -0.5 & - \\
\hline 700 & -0.3 & -0.4 & 2.2 \\
\hline 1000 & -0.3 & -0.4 & 2.3 \\
\hline 1158 & -0.4 & -0.4 & 2.3 \\
\hline Site & \multicolumn{3}{|c|}{$\begin{array}{c}\text { Sea of Okhotsk (MR06-4 St.4) } \\
\left(44^{\circ} 31^{\prime} \mathrm{N}, 145^{\circ} 00^{\prime} \mathrm{E}\right)\end{array}$} \\
\hline Water depth & \multicolumn{3}{|c|}{$1208 \mathrm{~m}$} \\
\hline $\begin{array}{l}\text { Depth in sediment } \\
(\mathrm{cm})\end{array}$ & $\begin{array}{r}10^{3} \times{ }^{13} \mathrm{C} \\
(\mathrm{VPDB})\end{array}$ & $\begin{array}{r}10^{3} \times \delta^{18} \mathrm{O} \\
(\mathrm{VSMOW})\end{array}$ & $\begin{array}{r}\text { Temperature } \\
\left({ }^{\circ} \mathrm{C}\right)\end{array}$ \\
\hline Bottom water & -0.4 & -0.3 & 2.3 \\
\hline 2 & -0.2 & -0.4 & \\
\hline 4 & -0.3 & -0.6 & \\
\hline 7 & -0.6 & -0.5 & \\
\hline 60 & - & -0.4 & \\
\hline Site & \multicolumn{3}{|c|}{$\begin{array}{l}\text { Nankai Trough } \\
\quad\left(33^{\circ} 40^{\prime} \mathrm{N}, 136^{\circ} 37^{\prime} \mathrm{E}\right)\end{array}$} \\
\hline Water depth & \multicolumn{3}{|c|}{$2040 \mathrm{~m}$} \\
\hline $\begin{array}{l}\text { Depth in sediment } \\
(\mathrm{cm})\end{array}$ & $\begin{array}{r}10^{3} \times \delta^{13} \mathrm{C} \\
(\mathrm{VPDB})\end{array}$ & $\begin{array}{l}10^{3} \times \delta^{18} \mathrm{O} \\
(\mathrm{VSMOW})\end{array}$ & $\begin{array}{r}\text { Temperature } \\
\left({ }^{\circ} \mathrm{C}\right)\end{array}$ \\
\hline Bottom water & -1.0 & -0.1 & 1.9 \\
\hline 1 & -1.2 & -0.1 & \\
\hline 2 & -1.3 & -0.2 & \\
\hline 3 & -2.6 & -0.2 & \\
\hline 5 & -2.9 & 0.0 & \\
\hline 7 & -2.7 & -0.2 & \\
\hline 9 & -2.6 & -0.3 & \\
\hline Site & \multicolumn{3}{|c|}{$\begin{array}{l}\text { Sagami Bay } \\
\quad\left(35^{\circ} 00^{\prime} \mathrm{N}, 139^{\circ} 14^{\prime} \mathrm{E}\right)\end{array}$} \\
\hline Water depth & $1182 \mathrm{~m}$ & & \\
\hline $\begin{array}{l}\text { Depth in sediment } \\
(\mathrm{cm})\end{array}$ & $\begin{array}{r}10^{3} \times \delta^{13} \mathrm{C} \\
(\mathrm{VPDB})\end{array}$ & $\begin{array}{l}10^{3} \times \delta^{18} \mathrm{O} \\
(\mathrm{VSMOW})\end{array}$ & $\begin{array}{r}\text { Temperature } \\
\left({ }^{\circ} \mathrm{C}\right)\end{array}$ \\
\hline Bottom water & 0.0 & -0.2 & 2.9 \\
\hline
\end{tabular}

al., 2004; Fontanier et al., 2006; Basak et al., 2009). The $\delta^{18} \mathrm{O}_{\text {e.c. }}$ values were calculated using equations proposed by Friedman and O'Neil (1977), which is the same procedure as in previous studies (Fontanier et al., 2006; Basak et al., 2009). The bottom-water temperatures at the study sites were $2.3^{\circ} \mathrm{C}$ in the Sea of Okhotsk (Matsunaga and 
Tanaka, 2006), $1.9^{\circ} \mathrm{C}$ in the Nankai Trough (Hamamoto et al., 2005), and $2.9^{\circ} \mathrm{C}$ in Sagami Bay.

\subsection{Reliability of microscale isotopic analysis of carbonate}

The reliability of isotope analysis for samples larger than $0.2 \mu \mathrm{g} \mathrm{CaCO}_{3}$ has already been demonstrated (Ishimura et al., 2004, 2008). The same analytical procedures can be used to analyze sub-microgram quantities to several hundred micrograms of carbonate. We did not observe any evidence of added errors from foraminiferal sampling (e.g. addition of authigenic carbonate, staining by Rose Bengal, etc.) or any systematic analytical errors (e.g. leakage of air, isotopic fractionation). In addition, to clarify the possibility of $\mathrm{CO}_{2}$ gas generation through the reaction between acid and organic materials, we checked whether foraminiferal soft tissues react with acid. We did not find the generation of $\mathrm{CO}_{2}$ gas from soft tissue over several days of observation.

\section{Results and discussion}

We obtained a dataset that included (1) $\delta^{13} \mathrm{C}$ and $\delta^{18} \mathrm{O}$ of foraminifera and water samples, (2) weights of individual shells, (3) isotopic distributions within species (interindividual isotopic variations), and (4) weighted average isotope values for each species (inter-species isotopic variations). The isotopic values of bottom water are shown in Table 1. All analytical results from foraminiferal shells are shown in Table 2. No systematic difference was observed in isotopic values between living (Rose Bengal stained) and dead individuals, and isotopic differences among shells collected from different depths were within the range of interindividual isotopic deviations for each species. This means there is no noticeable relationship between individual isotopic compositions within the same species and the sediment depth at which individuals were collected. The analyzed individuals show various inter-species differences in $\Delta \delta^{13} \mathrm{C}$ and $\Delta \delta^{18} \mathrm{O}$, together with species-specific inter-individual variations. The average single-shell isotopic values approximately corresponded to the average values from five shells analyzed together, confirming that inter-species differences in average isotopic values were not due to the reduced sample size (Table 2).

\subsection{Characteristics of isotopic disequilibrium in benthic foraminifera: choosing more reliable species as bottom-water indicator}

We calculated the difference between $\delta^{13} \mathrm{C}$ values of foraminifera and DIC in bottom water $\left(\Delta \delta^{13} \mathrm{C}\right)$ and between $\delta^{18} \mathrm{O}$ values of foraminifera and calcite in equilibrium with bottom water $\left(\Delta \delta^{18} \mathrm{O}\right)$. The individual foraminifera showed inter-species differences in $\Delta \delta^{13} \mathrm{C}$ and $\Delta \delta^{18} \mathrm{O}$, as well as variation of inter-individual isotopic dispersions among species (Fig. 4 and Table 2). The magnitude of interindividual isotopic dispersion of Bulimina aculeata was identical within the analytical precision, and their isotopic values were almost the same as the $\delta^{13} \mathrm{C}$ of DIC in bottom water $\left(\delta^{13} \mathrm{C}_{\mathrm{DIC}}\right)$ and $\delta^{18} \mathrm{O}$ of calcite in equilibrium with bottom water $\left(\delta^{18} \mathrm{O}_{\text {e.c. }}\right)$. Although Uvigerina akitaensis and the Cassidulina group (Islandiella norcrossi, Cassidulina norvangi, and Takayanagia delicata) showed slightly negative average $\Delta \delta^{13} \mathrm{C}$ values, their $\delta^{18} \mathrm{O}$ values were close to $\delta^{18} \mathrm{O}_{\text {e.c. }}$ values, with smaller deviations ( $\mathrm{SD}<0.4 \%$, Fig. 4 ). These small inter-individual variations in isotopic composition and mean $\delta^{13} \mathrm{C}$ and $\delta^{18} \mathrm{O}$ values close to seawater demonstrate the usefulness of these species for estimating the past isotopic composition of deep-sea water from even a limited number of individuals. Other species exhibited inter-individual isotopic variations substantially greater than the analytical precision. Moreover, $\Delta \delta^{13} \mathrm{C}$ and $\Delta \delta^{18} \mathrm{O}$ values in Brizalina pacifica and Stainforthia loeblichi were extremely negative compared with previously reported values for benthic foraminifera (Grossman, 1987; Rathburn et al., 1996; McCorkle et al., 1997; Mackensen and Licari, 2004; Fontanier et al., 2006).

All species tended to show ${ }^{13} \mathrm{C}$ - and ${ }^{18} \mathrm{O}$-enriched $\Delta \delta^{13} \mathrm{C}$ and $\Delta \delta^{18} \mathrm{O}$ values in proportion to individual weight (Fig. 5a). Also, the $\Delta \delta^{13} \mathrm{C}$ and $\Delta \delta^{18} \mathrm{O}$ values were inversely proportional to shell weight, and larger (heavier) individuals tended to have isotopic values closer to $\delta^{13} \mathrm{C}_{\mathrm{DIC}}$ and $\delta^{18} \mathrm{O}_{\text {e.c. }}$. (Fig. 5b, Supplement Fig. 1). The isotopic shift associated with growth stage has been reported as the "ontogenetic isotope effect" for some larger species (Schmiedl et al., 2004; Fontanier et al., 2006; McCorkle et al., 2008; Schumacher et al., 2010). We found that this trend is not limited to certain species but is common among species. Our initial findings show that species with low inter-individual deviations in isotopic composition are more suitable as direct proxies of the bottom-water environment. Moreover, the magnitude of the inter-species and inter-individual isotopic variations can be simplified to its correlation with the mass of the individual calcite shell.

\subsection{Application of inter-individual isotopic variations to estimate more reliable isotopic values of bottom water in the past.}

Although we found that the species with smaller interindividual isotopic deviations are more suitable as environmental proxies, some of those species ( $U$. akitaensis and the Cassidulina group) had carbon isotopic values that were slightly negative relative to ambient $\delta^{13} \mathrm{C}_{\text {DIC }}$ $\left(\Delta \delta^{13} \mathrm{C} \approx-2 \%\right.$ ). Therefore, we could not correctly estimate the original $\delta^{13} \mathrm{C}_{\text {DIC }}$ values of water by using isotopic evidence from these species. However, Fig. 4 displays a trend of proportionally more negative average $\Delta \delta^{13} \mathrm{C}$ and $\Delta \delta^{18} \mathrm{O}$ values of species with increasing inter-individual variations. We determined the relationship between average $\delta^{13} \mathrm{C}$ and $\delta^{18} \mathrm{O}$ 
Table 2. $\delta^{13} \mathrm{C}$ and $\delta^{18} \mathrm{O}$ values of individual foraminiferal shells collected from the surface sediment at study sites, as well as the averages of multiple specimens analyzed together. $\Delta \delta^{13} \mathrm{C}$, isotopic difference between the $\delta^{13} \mathrm{C}$ of analyzed foraminiferal shell and the $\delta^{13} \mathrm{C}$ of DIC $\left(\delta^{13} \mathrm{C}_{\mathrm{DIC}}\right)$ in bottom water; $\Delta \delta^{18} \mathrm{O}$, isotopic difference between the $\delta^{18} \mathrm{O}$ of analyzed foraminifera and the $\delta^{18} \mathrm{O}$ of calcite in equilibrium with bottom water $\left(\delta^{18} \mathrm{O}_{\text {e.c. }}\right.$ ). Results of $\delta^{13} \mathrm{C}$ and $\delta^{18} \mathrm{O}$ analysis for Cassidulina norvangi reported in a previous study (Ishimura et al., 2004) are denoted by an asterisk. Living: Rose Bengal-stained. Cmbsf: $\mathrm{cm}$ below the sea floor.

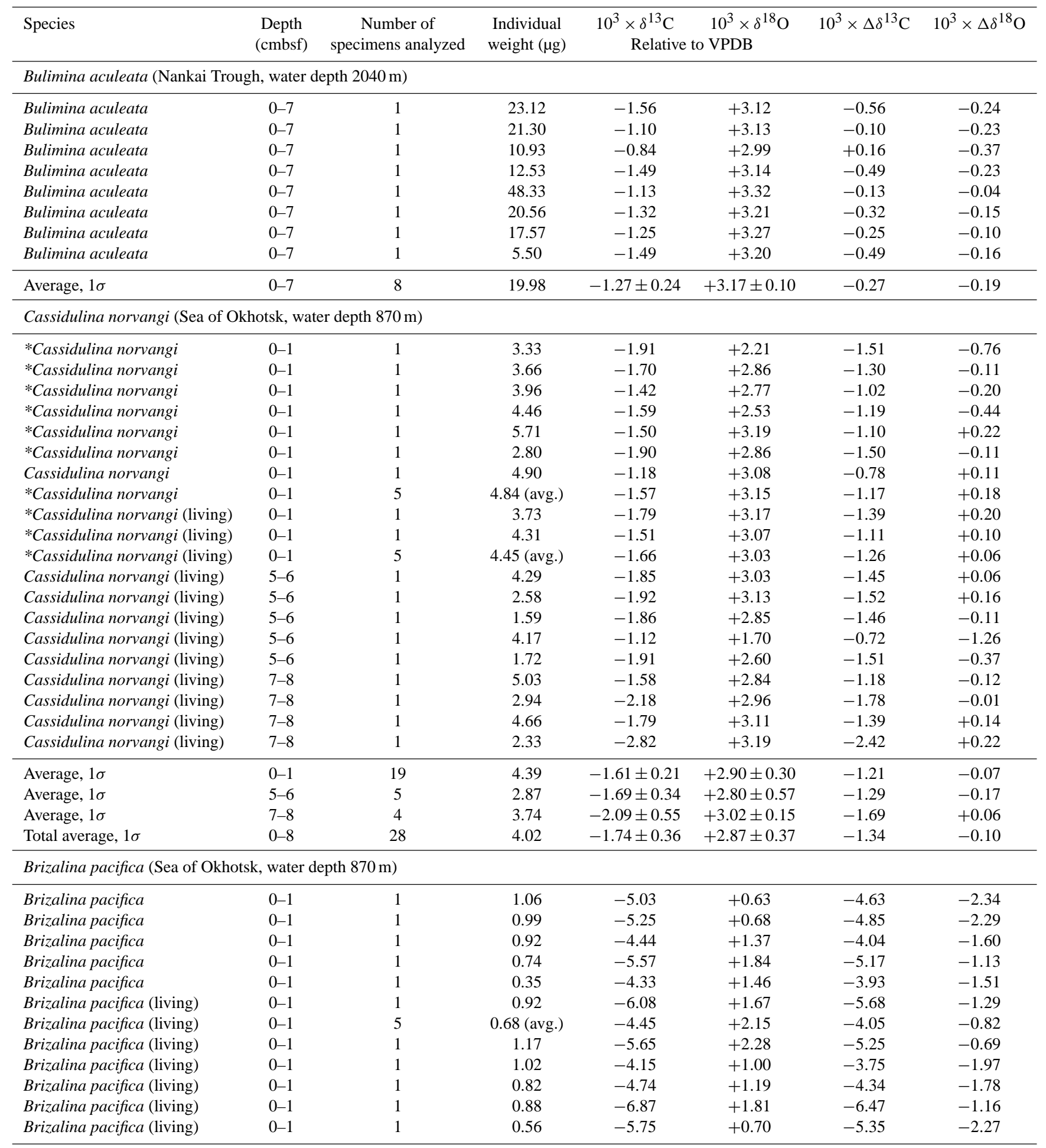


Table 2. Continued.

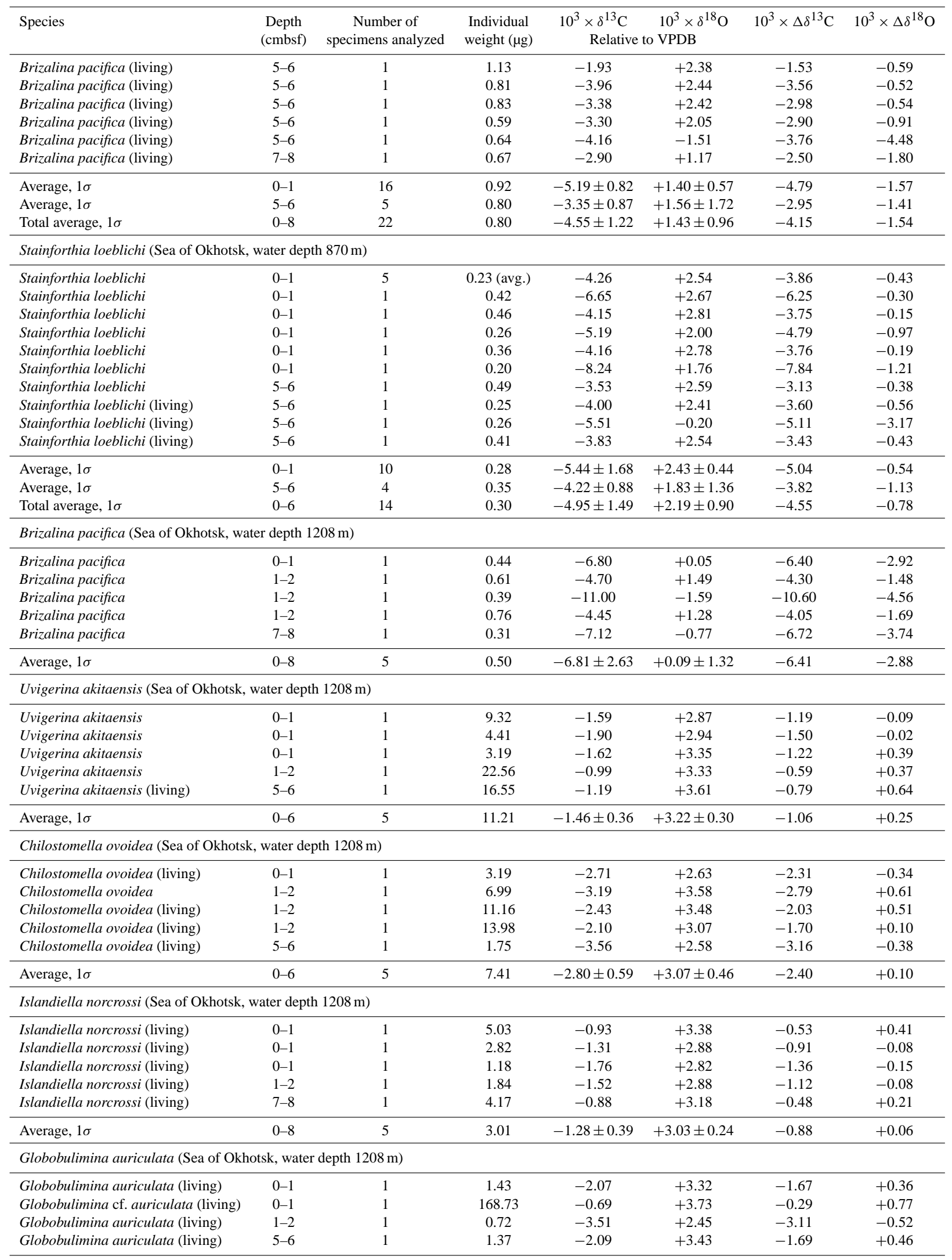


Table 2. Continued.

\begin{tabular}{|c|c|c|c|c|c|c|c|}
\hline Species & $\begin{array}{l}\text { Depth } \\
\text { (cmbsf) }\end{array}$ & $\begin{array}{c}\text { Number of } \\
\text { specimens analyzed }\end{array}$ & $\begin{array}{c}\text { Individual } \\
\text { weight }(\mu g)\end{array}$ & \multicolumn{2}{|c|}{ Relative to VPDB } & $10^{3} \times \Delta \delta^{13} \mathrm{C}$ & $10^{3} \times \Delta \delta^{18} \mathrm{O}$ \\
\hline Globobulimina auriculata (living) & $5-6$ & 1 & 0.51 & -3.80 & +1.93 & -3.40 & -1.04 \\
\hline Average, $1 \sigma$ & $0-6$ & 5 & 34.55 & $-2.43 \pm 1.26$ & $+2.97 \pm 0.76$ & -2.03 & +0.01 \\
\hline Average, $1 \sigma$ (small individual) & $0-6$ & 4 & 1.01 & $-2.87 \pm 0.92$ & $+2.78 \pm 0.72$ & -2.47 & -0.19 \\
\hline \multicolumn{8}{|c|}{ Takayanagia delicata (Sea of Okhotsk, water depth 1208 m) } \\
\hline Takayanagia delicata (living) & $0-1$ & 1 & 3.43 & -1.58 & +3.24 & -1.18 & +0.27 \\
\hline Takayanagia delicata (living) & $0-1$ & 1 & 2.09 & -2.15 & +3.01 & -1.75 & +0.04 \\
\hline Takayanagia delicata (living) & $1-2$ & 1 & 2.37 & -2.38 & +2.61 & -1.98 & -0.36 \\
\hline Takayanagia delicata (living) & $5-6$ & 1 & 1.70 & -2.52 & +2.90 & -2.12 & -0.06 \\
\hline Takayanagia delicata (living) & $7-8$ & 1 & 3.07 & -2.10 & +2.88 & -1.70 & -0.08 \\
\hline Average, $1 \sigma$ & $0-8$ & 5 & 2.53 & $-2.14 \pm 0.36$ & $+2.93 \pm 0.23$ & -1.74 & -0.04 \\
\hline \multicolumn{8}{|c|}{ Globobulimina auriculata (Sagami Bay, water depth 1182 m) } \\
\hline Globobulimina auriculata (living) & $0-2$ & 1 & 31.9 & -3.43 & +2.92 & -3.41 & -0.05 \\
\hline Globobulimina auriculata (living) & $0-2$ & 1 & 43.4 & -3.65 & +3.32 & -3.63 & +0.35 \\
\hline Globobulimina auriculata (living) & $0-2$ & 1 & 49.8 & -1.58 & +2.22 & -1.56 & -0.75 \\
\hline Globobulimina auriculata (living) & $0-2$ & 1 & 7.4 & -3.25 & +2.78 & -3.23 & -0.18 \\
\hline Globobulimina auriculata (living) & $0-2$ & 1 & 44.4 & -2.43 & +3.29 & -2.41 & +0.32 \\
\hline Globobulimina auriculata (living) & $0-2$ & 1 & 5.9 & -1.81 & +3.03 & -1.79 & +0.06 \\
\hline Average, $1 \sigma$ & & 6 & 30.5 & $-2.69 \pm 0.88$ & $+2.93 \pm 0.41$ & -2.67 & -0.04 \\
\hline \multicolumn{8}{|c|}{ Chilostomella ovoidea (Sagami Bay, water depth 1182 m) } \\
\hline Chilostomella ovoidea (living) & $0-2$ & 1 & 4.7 & -2.95 & +2.89 & -2.93 & -0.08 \\
\hline Chilostomella ovoidea (living) & $0-2$ & 1 & 2.5 & -5.25 & +1.61 & -5.23 & -1.36 \\
\hline Chilostomella ovoidea (living) & $0-2$ & 1 & 6.5 & -4.34 & +2.94 & -4.32 & -0.03 \\
\hline Chilostomella ovoidea (living) & $0-2$ & 1 & 5.8 & -2.49 & +1.57 & -2.47 & -1.40 \\
\hline Chilostomella ovoidea (living) & $0-2$ & 1 & 5.9 & -3.27 & +2.73 & -3.25 & -0.24 \\
\hline Chilostomella ovoidea (living) & $0-2$ & 1 & 4.9 & -4.94 & +3.02 & -4.92 & +0.05 \\
\hline Average, $1 \sigma$ & & 6 & 5.0 & $-3.87 \pm 1.13$ & $+2.46 \pm 0.68$ & -3.85 & -0.51 \\
\hline \multicolumn{8}{|c|}{ Rutherfordoides cornuta (Sagami Bay, water depth 1182 m) } \\
\hline Rutherfordoides cornuta (living) & $0-2$ & 1 & 4.5 & -1.18 & +0.55 & -1.16 & -2.42 \\
\hline Rutherfordoides cornuta (living) & $0-2$ & 1 & 6.5 & -0.88 & +2.92 & -0.86 & -0.05 \\
\hline Rutherfordoides cornuta (living) & $0-2$ & 1 & 3.9 & -1.56 & +2.47 & -1.54 & -0.50 \\
\hline Rutherfordoides cornuta (living) & $0-2$ & 1 & 7.5 & -0.96 & +3.07 & -0.94 & +0.10 \\
\hline Rutherfordoides cornuta (living) & $0-2$ & 1 & 5.3 & -1.13 & +2.58 & -1.11 & -0.39 \\
\hline Rutherfordoides cornuta (living) & $0-2$ & 1 & 3.9 & -0.95 & +2.61 & -0.93 & -0.36 \\
\hline Average, $1 \sigma$ & & 6 & 5.3 & $-1.11 \pm 0.25$ & $+2.37 \pm 0.92$ & -1.09 & -0.60 \\
\hline
\end{tabular}

values and inter-individual distributions (SD within species) at the two sites in the Sea of Okhotsk (Fig. 6a and b). The regression lines all have high correlation coefficients $(r>0.9$, $p<0.05$ ), indicating that the coefficients of variation are almost constant. Note that the p-value was calculated for all $\Delta \delta^{13} \mathrm{C}$ and $\Delta \delta^{18} \mathrm{O}$ isotopic values of analyzed species of two stations in the Sea of Okhotsk. Moreover, the intercepts of the regression lines (at $\mathrm{SD}=0$ ) for $\delta^{13} \mathrm{C}$ are almost identical to the $\delta^{13} \mathrm{C}_{\text {DIC }}$ (Table 3). In foraminiferal samples collected from Sagami Bay, we found the same trend in the $\delta^{13} \mathrm{C}$ profile (Fig. 6c), and the intercept of the regression line also corresponded to the $\delta^{13} \mathrm{C}_{\text {DIC }}$ values in the bay. The differences between the intercept values and the actual $\delta^{13} \mathrm{C}_{\mathrm{DIC}}$ at these three sites are within $0.3 \%$, substantially closer to $\delta^{13} \mathrm{C}_{\text {DIC }}$ than the $\Delta \delta^{13} \mathrm{C}$ values of all species.
We conclude that we can more reliably estimate $\delta^{13} \mathrm{C}_{\text {DIC }}$ values of bottom water by accounting for the vital effect in foraminifera. This technique promises to yield $\delta^{13} \mathrm{C}$ data for bottom water where water samples are not available. However, there is still uncertainty in $\delta^{18} \mathrm{O}_{\text {e.c. }}$ values owing to changes of bottom-water temperature and analytical errors in measuring $\delta^{18} \mathrm{O}$ of water. In addition, the choice of equation for calculating $\delta^{18} \mathrm{O}_{\text {e.c. }}$ affects the results; for example there is a $0.7 \%$ difference in $\delta^{18} \mathrm{O}_{\text {e.c. }}$ values at our study sites as calculated by the equations of Friedman and O'Neil (1977) and Kim and O'Neil (1997). We propose applying the magnitude of isotopic disequilibrium using the inter-individual isotopic distributions of species as an index of the reliability of bottom-water isotope values. Also the $\delta^{13} \mathrm{C}_{\mathrm{DIC}}$ can be reconstructed from foraminiferal isotopes without water samples 

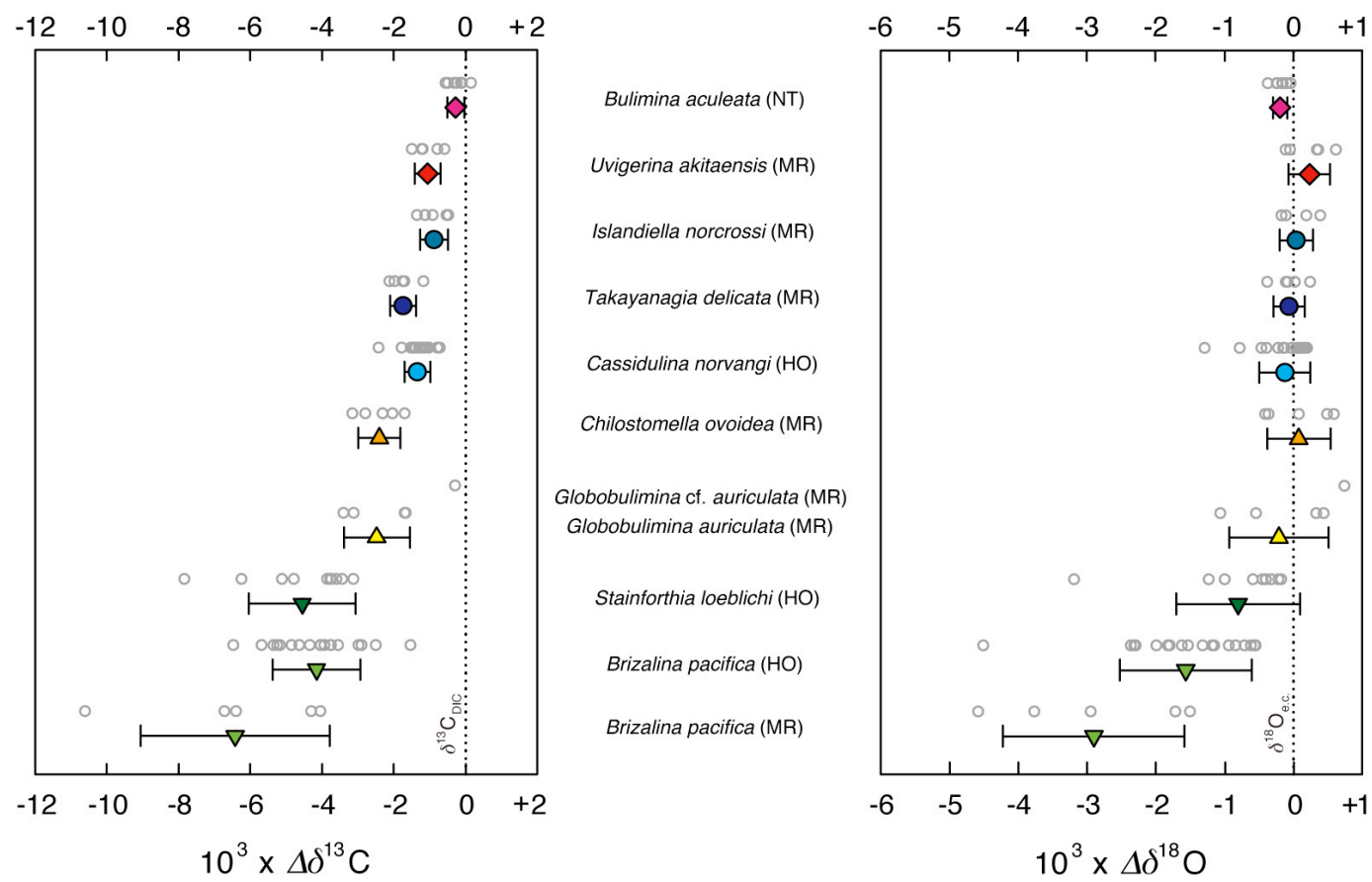

Fig. 4. Variations in $\Delta \delta^{13} \mathrm{C}$ and $\Delta \delta^{18} \mathrm{O}$ values of individual benthic foraminifera together with average values. Open circles are individual isotopic values. Colored symbols are average values with standard deviations (error bars). Dotted lines indicate the $\delta^{13} \mathrm{C}$ values of DIC in bottom water $\left(\delta^{13} \mathrm{C}_{\mathrm{DIC}}\right)$ and the $\delta^{18} \mathrm{O}$ values of calcite in equilibrium with bottom water $\left(\delta^{18} \mathrm{O}_{\text {e.c. }}\right)$. The $\delta^{18} \mathrm{O}_{\text {e.c. values were calculated }}$ using the equation proposed by Friedman and O’Neil (1977). NT, Nankai Trough (1881 m); MR, Sea of Okhotsk (1208 m); HO, Sea of Okhotsk $(870 \mathrm{~m})$.

Table 3. Comparison of predicted isotopic values of calcite in equilibrium with bottom water at the study sites (intercepts of regression lines in Fig. 6) and the actual isotopic values of calcite in equilibrium with bottom water.

\begin{tabular}{|c|c|c|c|c|c|}
\hline \multicolumn{6}{|c|}{ Isotopic values of calcite in equilibrium with bottom water } \\
\hline \multirow{3}{*}{ Site } & \multicolumn{3}{|c|}{ Estimated values (intercepts of regression lines in Fig. 6) } & \multicolumn{2}{|c|}{ Actual values } \\
\hline & $10^{3} \times \delta^{13} \mathrm{C}_{\text {DIC }}$ & & $10^{3} \times \delta^{18} \mathrm{O}_{\text {e.c. }}$ & $10^{3} \times \delta^{13} \mathrm{C}_{\text {DIC }}$ & $10^{3} \times \delta^{18} \mathrm{O}_{\text {e.c. }}$ \\
\hline & & Relative to VPDB & & Relative & o VPDB \\
\hline Sea of Okhotsk (water depth $1208 \mathrm{~m}$ ) & -0.6 & & $+4,0$ & -0.4 & $+3,0$ \\
\hline Sea of Okhotsk (water depth $870 \mathrm{~m}$ ) & -0.7 & & +3.6 & -0.4 & +3.0 \\
\hline Sagami Bay (water depth 1182 m) & -0.3 & & +3.3 & -0.0 & +3.0 \\
\hline
\end{tabular}

by correcting for the isotopic disequilibrium. This permits the utilization of stored sediment samples, even those with no associated isotopic data for bottom water. In addition, we can estimate the absolute $\delta^{13} \mathrm{C}$ changes in the ocean bottom by comparing the calibrated isotope values to the relative $\delta^{13} \mathrm{C}$ curves previously reported, and thereby better understand environmental changes.

Although there was a good correlation between SD and $\Delta \delta^{13} \mathrm{C}$ of benthic foraminifera in same sampling site, the empirical relations of SD and $\Delta \delta^{13} \mathrm{C}$ may not always be the same among different environmental conditions (redox condition, flux of organic matter, bottom-water chemistry, etc.). By studying various sites, we were able to clarify the detailed characteristics of the relationship between the magnitude of $\mathrm{SD}$ and $\Delta \delta^{13} \mathrm{C}$ of benthic foraminifera.

\subsection{Possible causes of inter-species and inter-individual isotopic variations}

Part of the inter-individual variability in $\delta^{13} \mathrm{C}$ may be caused by the isotopic variability of DIC in sediment pore water, which is caused by the decomposition of organic matter, and a wider range of depth habitats may result in large interindividual variability in isotopic compositions. However, even considering the isotopic variation in sediments owing to the decomposition of organic matter and the presence of a geothermal gradient, we cannot account for the extremely 
a
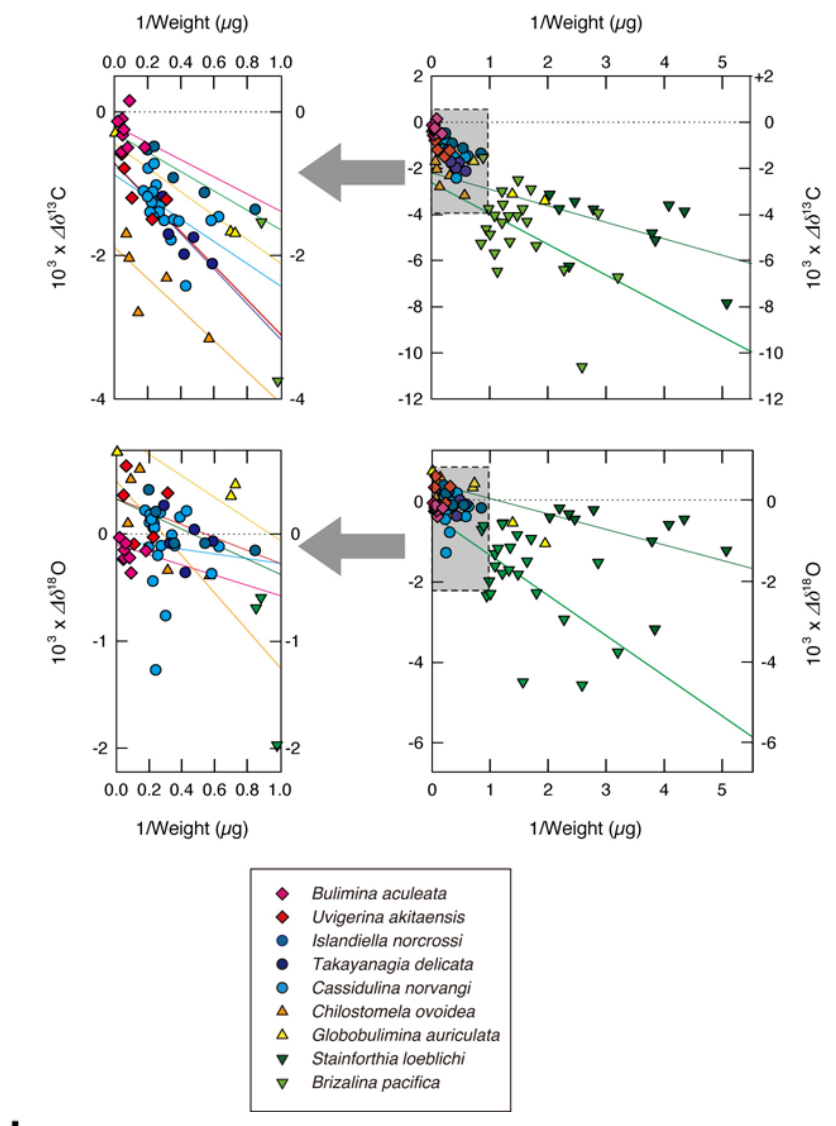

b

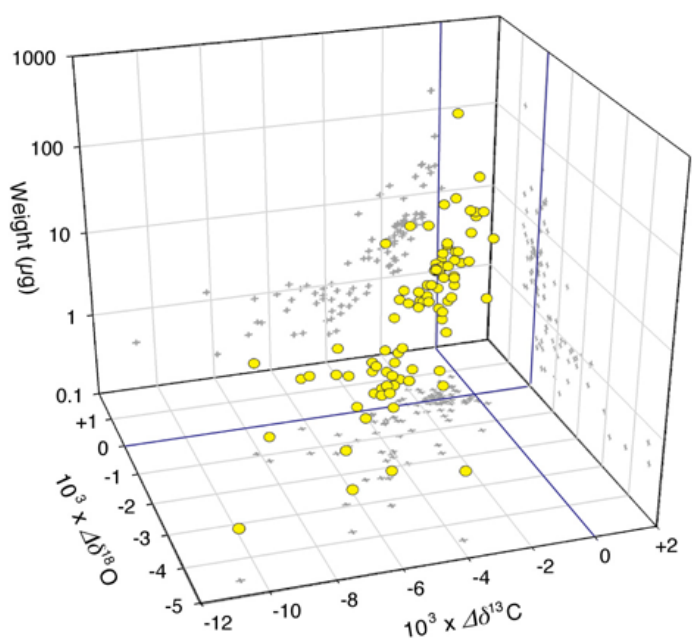

Fig. 5. Relationship between shell weight and $\Delta \delta^{13} \mathrm{C}$ and $\Delta \delta^{18} \mathrm{O}$ values of individual benthic foraminifera. (a) $\Delta \delta^{13} \mathrm{C}$ and $\Delta \delta^{18} \mathrm{O}$ values of all individual benthic foraminifera analyzed plotted as a function of inverse shell weight. Lines are linear regressions fitted to each species. (b) Three-dimensional plot of $\Delta \delta^{13} \mathrm{C}, \Delta \delta^{18} \mathrm{O}$, and shell weight (animation available as Supplement Fig. 1). (a)
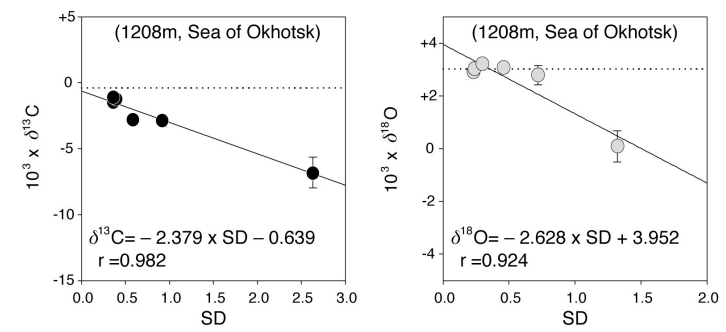

(b)
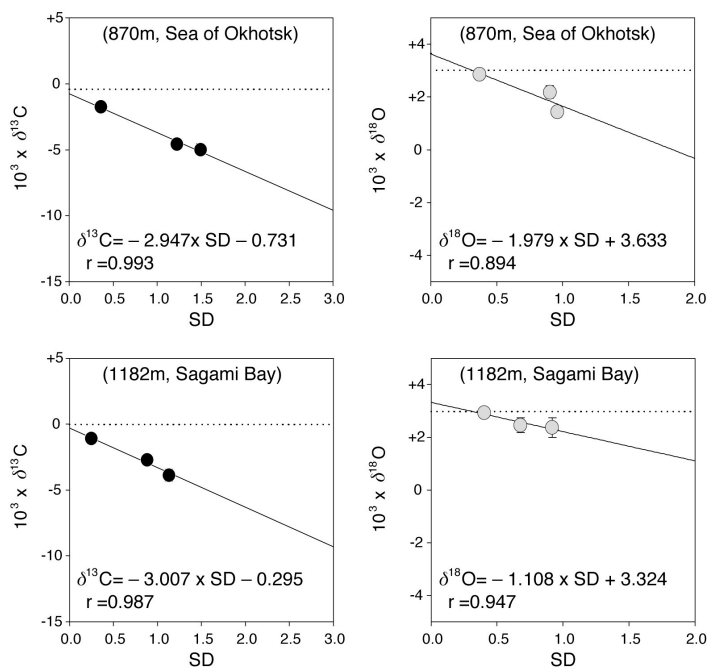

Fig. 6. Relationships between average $\delta^{13} \mathrm{C}$ and $\delta^{18} \mathrm{O}$ values and inter-individual variations (SD; standard deviation) for each species of benthic foraminifera analyzed. (a) Sea of Okhotsk, $1208 \mathrm{~m}$ bottom depth; (b) Sea of Okhotsk, 870 m; (c) Sagami Bay, $1182 \mathrm{~m}$. Solid lines and equations are linear regression results. Dotted lines represent $\delta^{13} \mathrm{C}_{\mathrm{DIC}}$ and $\delta^{18} \mathrm{O}_{\text {e.c. }}$ at each site. Error bars indicate the range of standard error for each species.

negative isotopic values and the large inter-individual variation in $\delta^{13} \mathrm{C}$ and $\delta^{18} \mathrm{O}$, especially observed in $B$. pacifica and $S$. loeblichi. The $\delta^{13} \mathrm{C}$ values of most individuals were much lower than $\delta^{13} \mathrm{C}_{\mathrm{DIC}}$ values of pore water at the sediment depth of which they had been taken (Tables 1 and 2). Furthermore, the $\delta^{18} \mathrm{O}$ variation of $6 \%$ among species (Fig. 4) corresponds to a temperature difference of $\pm 24^{\circ} \mathrm{C}$, which is greater than the geothermal gradient. Also, we could not explain the variability of $\delta^{18} \mathrm{O}$ on the basis of differences of microhabitat because the decomposition of organic matter does not change the $\delta^{18} \mathrm{O}$ value of pore water. In fact, the $\delta^{18} \mathrm{O}$ values of pore water at each sediment-depth indicate almost homogeneous isotopic values (the $\delta^{18} \mathrm{O}$ variation among different sediment depths is almost the same as the analytical error). The isotopic variation may instead be related to the carbonate ion concentration $\left(\left[\mathrm{CO}_{3}^{2-}\right]\right)$ effect that is hypothesized as controlling $\delta^{13} \mathrm{C}$ and $\mathrm{g} \delta^{18} \mathrm{O}$ in calcifying organisms (Spero et al., 1997). $\delta^{18} \mathrm{O}$ in planktonic foraminifera decreases with increasing $\left[\mathrm{CO}_{3}^{2-}\right]$ and $\mathrm{pH}$ (Spero et al., 1997). We observed a similar trend in the isotopic shift among benthic species (Fig. 7). This 


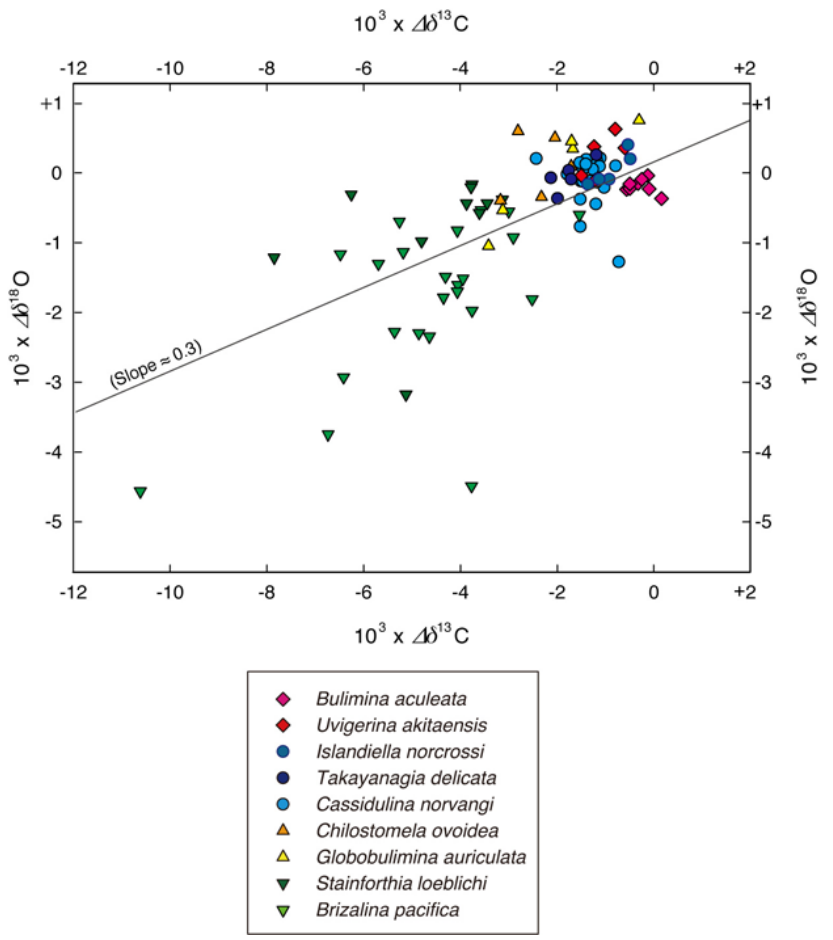

Fig. 7. Relationship between $\Delta \delta^{13} \mathrm{C}$ and $\Delta \delta^{18} \mathrm{O}$ of individual benthic foraminifera. Solid line indicates the reported trend of the isotopic shift caused by the carbonate ion concentration effect (Spero et al., 1997).

similarity between laboratory experiments with planktonic foraminifera and our natural samples of benthic foraminifera suggests that the inter-individual and inter-species isotopic variations are strongly affected by the $\left[\mathrm{CO}_{3}^{2-}\right]$ effect. However, infaunal species, such as B. pacifica and S. loeblichi in particular, should have positive isotopic values because of the low $\mathrm{pH}$ and decreased $\left[\mathrm{CO}_{3}^{2-}\right]$ of ambient water in sediment resulting from decomposition of organic matter (Bemis et al., 1998). Our results show the opposite trend.

Recent findings suggest a novel explanation for the extremely negative and heterogeneous inter-individual isotopic compositions of some benthic foraminifera. One study of intracellular calcification found that a widespread strategy among benthic foraminifera is to elevate the $\mathrm{pH}$ at the site of calcification to promote calcite precipitation, and described a mechanism that produces a ${ }^{13} \mathrm{C}$-depleted foraminiferal shell (de Nooijer et al., 2009). This mechanism would explain the negative shift of $\Delta \delta^{13} \mathrm{C}$ and $\Delta \delta^{18} \mathrm{O}$. Heterogeneity of $\mathrm{pH}$ in foraminiferal cells may thus be one cause of the interindividual differences in isotopic compositions observed in this study. In addition, the inter-species variability in isotopic compositions may be caused by the magnitude of $\mathrm{pH}$ control by different species (or by the inter-species variability in the pool of respired $\mathrm{CO}_{2}$ that participates in calcification).

Another study reported that some benthic foraminifera accumulate intracellular nitrate stores that are respired through denitrification (Risgaard-Petersen et al., 2006), and nitrate pooling is reported as common in foraminifera, including species closely related to B. pacifica and S. loeblichi, from very diverse benthic marine environments (Pina-Ochoa et al., 2010). High concentrations of nitrate in such species suggest that they make semi-closed system of their cell to store the materials to use. Evidence for isotopic fractionation of $\delta^{18} \mathrm{O}$ through denitrification has been reported previously (Sigman et al., 2005), indicating that ${ }^{18} \mathrm{O}$-depleted nitrate is respired during denitrification. Although details of the isotopic fractionation through respiration and calcification in foraminiferal cells are not well known, its respiration through intracellular denitrification and the contributions of respired $\mathrm{CO}_{2}$ in semi-closed system are expected to alter the isotopic composition and the magnitude of isotopic variation. Moreover, both intracellular calcification and denitrification occur at the individual level and any associated isotopic fractionation would affect individuals and not the entire population, thus potentially leading to larger inter-individual isotopic differences.

However, vital effects were originally thought to result from the incorporation of isotopically depleted carbon and oxygen compounds derived from the metabolic $\mathrm{CO}_{2}$ pool within an organism into its shell (Grossman, 1987; Erez, 2003). It appears that these metabolic vital effects, some other vital effects (Rohling and Cooke, 1999; Mackensen, 2008), and microenvironmental heterogeneity (Mackensen et al., 1993) play roles in the observed inter-individual differences in isotopic signatures, and their intensity is reflected in the magnitude of inter-individual isotopic variations. In addition, previous studies reported that Stainforthia fusiformis has kleptoplasts (Bernhard and Alve, 1996), and that $B$. pacifica has ectobionts (Bernhard et al., 2010b; reported as Bolivina pacifica). As discussed in these studies, the activities of symbionts might more or less affect the isotopic compositions of those species. Further in situ biological observations and culture experiments (e.g. Spero et al., 1997; Hintz et al., 2004; Nomaki et al., 2005; Risgaard-Petersen et al., 2006; McCorkle et al., 2008; de Nooijer et al., 2009; Pina-Ochoa et al., 2010) should help to clarify the mechanisms responsible for large inter-individual isotopic variations in foraminifera.

\section{Conclusions}

In this study, we show a simplified analysis of the magnitude of isotopic disequilibrium in benthic foraminifera based on inter-individual isotopic variations, and its application to estimating bottom-water conditions precisely.

We analyzed isotopes in individual foraminifera of multiple benthic species from four sites in continental margin of the northwestern Pacific Ocean to characterize the magnitude of inter-individual isotopic variations. We found that the species with low inter-individual isotopic dispersion 
are more suitable as direct proxies of the bottom-water environment. Moreover, the magnitude of the inter-species and inter-individual isotopic variations can be simplified to its correlation with the mass of the individual calcite shell.

Comparing the isotopic values of benthic foraminifera collected from the same sampling site, we found that the magnitude of the isotopic disequilibrium in each species (interspecies isotopic variations) was correlated with the interindividual isotopic dispersion. Furthermore, by using the simplified interpretation of the isotopic disequilibrium established in this study, we can reconstruct $\delta^{13} \mathrm{C}$ values of dissolved inorganic carbon in bottom water from foraminiferal isotopic compositions, by correcting for the isotopic disequilibrium. By studying various sites, we will be able to clarify the more detailed characteristics of the relationship between the magnitude of inter-individual isotopic dispersions and $\Delta \delta^{13} \mathrm{C}$ of benthic foraminifera.

\section{Appendix A}

\section{Faunal reference list}

Bulimina aculeata d'Orbigny, 1826 [Fig. 3b]. Bulimina aculeata d'Orbigny, 1826, p. 269; Parker, Jones and Brady, 1871, p. 172, pl. 11, Fig. 128.

Brizalina pacifica (Cushman and McCulloch, 1942) [Fig. 3j] Bolivina acerosa var. pacifica Cushman and McCulloch, 1942, p. 185, pl. 21, Figs. 2-3.

Cassidulina norvangi Thalmann, 1952 [Fig. 3d] Cassidulina islandica Nørvang forma minuta Nørvang, 1945, p. 43, text-Figs. 8a-c (fide Ellis and Messina, 1940 et seq.). Cassidulina islandica Nørvang var. norvangi Thalmann in Phleger, 1952, p. 83, footnote 1; Phleger, 1952, pl. 14, Fig. 30. Cassidulina norvangi Thalmann, Nomura, 1983b, p. 53, pl. 4, Figs. 12, 13; pl. 23, Figs. 10-12,; pl. 24, Figs. 1-3.

Chilostomella ovoidea Reuss, 1850 [Fig. 3c] Chilostomella ovoidea Reuss, 1850, p. 380., pl. 48, Figs. 12a-e.

Globobulimina auriculata (Bailey) [Fig. 3g] Bulimina auriculata Bailey, 1851, p. 12, Figs. 25-27. Globobulimina auriculata (Bailey); Asano, 1958, p. 9, pl. 2, Figs. 1-3.

Islandiella norcrossi (Cushman) [Fig. 3f] Cassidulina norcrossi Cushman, 1933, p. 7, pl. 2, Fig. 7a-c. Islandiella norcrossi (Cushman, 1933), Nørvang, 1958 (part), p. 32, pl. 7, Figs. 8, 9, 11, pl. 8, Fig. 14 (not pl. 7, Figs. 10, 12, 13).

Rutherfordoides cornuta (Cushman) [Fig. 3h] Virgulina cornuta Cushman, 1913, p. 637, pl. 80, Figs. 1a-c; Rutherfordoides cornuta (Cushman, 1913), McCulloch, 1977, p. 249 , pl. 105, Fig. 5. (Generic name was originally Rutherfordia, but it has been replaced by the same auther (McCulloch, 1981, p. 6.)).

Stainforthia loeblichi (Feyling-Hanssen) [Fig. 3i] Virgulina loeblichi Feyling-Hanssen, 1954, p. 191, pl. 1, Figs. 14-18; text-Fig. 8; Stainforthia concave var., loe- blichi (Feyling-Hanssen), Feyling-Hanssen, 1973, p.123, pl. 5, Figs. 10.

Takayanagia delicata (Cushman, 1927) [Fig. 3e] Cassidulina delicata Cushman, 1927, p. 168, pl. 6, Fig. 5.; Takayanagia delicata (Cushman); Nomura, 1983a, p. 53, pl. 1, Figs. 3a-c; pl. 7, Figs. 1-5.

Uvigerina akitaensis Asano, 1950 [Fig. 3a] Uvigerina akitaensis Asano, 1950, pt. 2, p. 14, Figs. 60-62.

\section{Supplementary material related to this article is available online at: http://www.biogeosciences.net/9/ 4353/2012/bg-9-4353-2012-supplement.zip.}

Acknowledgements. We thank the chief scientists of our research cruises, T. Oba (Hokkaido University), S. Kuramoto and N. Harada (Japan Agency for Marine-Earth Science and Technology), for their kind help with on-board sampling; A. Suzuki (Geological Survey of Japan, National Institute of Advanced Industrial Science and Technology) and D. D. Komatsu (Hokkaido University) for their valuable suggestions; and S. Sakai and N. Ohkouchi (Japan Agency for Marine-Earth Science and Technology) for their support with analysis; and the on-board scientists and crewmembers of R/V Yokosuka and submersible Shinkai6500, R/V Mirai, R/V Hokusei, and R/V Tansei for collecting and processing the samples. We also thank Christophe Fontanier (University of Angers) and the two anonymous referees for their constructive comments to greatly improve this manuscript. This research was supported by KAKENHI 21740367 and 24651017 funded by the Japan Society for the Promotion of Science.

Edited by: J. Middelburg

\section{References}

Asano, K.: Illustrated Catalogue of Japanese Tertiary Smaller Foraminifera, edited by: Stach, L. W., Hosokawa Printing Co., Tokyo. Pt. 2, Buliminidae, 96 figs., 1-19, 1950.

Asano, K.: The foraminifera from the adjacent seas of Japan, collected by the S. S. Soyo-maru, 1922-1930, Pt. 4, Buliminidae, The Science Reports of the Tohoku University, 2nd ser. (Geology), 29, 1-41, 4 text-figs., pls. 1-7, 1958.

Bailey, J. W.: Microscopical examination of soundings made by the United States Coast Survey, off the Atlantic Coast of the United States, Smithsonian 1nst., Contr. Knowledge, Washington, DC, USA, 2, 3-15, pl. 1, 1851.

Basak, C., Rathburn, A. E., Perez, M. E., Martin, J. B., Kluesner, J. W., Levin, L. A., De Deckker, P., Gieskes, J. M., and Abriani, M.: Carbon and oxygen isotope geochemistry of live (stained) benthic foraminifera from the Aleutian Margin and the Southern Australian Margin, Mar. Micropaleontol., 70, 89-101, doi:10.1016/j.marmicro.2008.11.002, 2009.

Bemis, B. E., Spero, H. J., Bijma, J., and Lea, D. W.: Reevaluation of the oxygen isotopic composition of planktonic foraminifera: Experimental results and revised paleotemperature equations, Paleoceanography, 13, 150-160, 1998. 
Bernhard, J. M.: Postmortem vital staining in benthic foraminifera; duration and importance in population and distributional studies, J. Foramin. Res., 8, 143-146, doi:10.2113/gsjfr.18.2.143, 1988.

Bernhard, J. M. and Alve, E.: Survival, ATP pool, and ultrastructural characterization of benthic foraminifera from Drammensfjord (Norway): Response to anoxia, Mar. Micropaleontol., 28, 5-17, doi:10.1016/0377-8398(95)00036-4, 1996.

Bernhard, J. M., Ostermann, D. R., Williams, D. S., and Blanks, J. K.: Comparison of two methods to identify live benthic foraminifera: A test between Rose Bengal and CellTracker Green with implications for stable isotope paleoreconstructions, Paleoceanography, 21, PA4210, doi:10.1029/2006PA001290, 2006.

Bernhard, J. M., Martin, J. B., and Rathburn, A. E.: Combined carbonate carbon isotopic and cellular ultrastructural studies of individual benthic foraminifera: 2 . Toward an understanding of apparent disequilibrium in hydrocarbon seeps, Paleoceanography, 25, PA4206, doi:10.1029/2010PA001930, 2010a.

Bernhard, J. M., Goldstein, S. T., and Bowser, S. S.: An ectobiontbearing foraminiferan, Bolivina pacifica, that inhabits microxic pore waters: Cell-biological and paleoceanographic insights, Environ. Microbiol., 12, 2107-2119, doi:10.1111/j.14622920.2009.02073.x, 2010b.

Bijma, J., Spero, H. J., and Lea, D. W.: Reassessing foraminiferal stable isotope geochemistry: impact of the oceanic carbonate system (experimental results), in: Use of Proxies in Paleoceanography: Examples from the South Atlantic, edited by: Fischer, G. and Wefer, G., Springer-Verlag, Berlin, 489-512, 1999.

Cushman, J. A.: New Textulariidae and other arenaceous foraminifera from the Philippine Islands and contiguous waters, Proceedings US National Museum, Washington, DC, USA, 44, 633-638, 1913.

Cushman, J. A.: Recent foraminifera from off the west coast of America. Univ. California, Scripps Inst. Oceanogr., Bull., Tech. Ser., 1, 119-188, pls. 1-6, 1927.

Cushman, J. A.: New Arctic foraminifera collected by Captain R. A. Bartlett from Fox Basin and off the northeast coast of Greenland. Smithsonian Institution Miscellaneous Collections, Washington, DC, USA, 89, 9 (pub. 3221), 1933.

Cushman, J. A. and McCulloch, Y.: Some Virgulininae of the collections of the Allan Hancock Foundation, Allan Hancock Pacific Expeditions, 6, 179-230, pls. 21-28, 1942.

de Groot, P. A.: Handbook of Stable Isotope Analytical Techniques, Vol. II., Elsevier, Amsterdam, 1398 pp., 2008.

de Nooijer, L. J., Toyofuku, T., and Kitazato, H.: Foraminifera promote calcification by elevating their intracellular $\mathrm{pH}$, Proceedings of the National Academy of Sciences of the United States of America, 106, 15374-15378, doi:10.1073/pnas.0904306106, 2009.

Ellis, B. F. and Messina, A. R.: et seq., Catalogue of Foraminifera, American Museum of Natural History, New York, 30 vols. and supplement-vols., 1940.

Emiliani, C.: Pleistocene temperatures, J. Geol., 63, 538-578, 1955.

Erez, J.: The source of ions for biomineralization in foraminifera and their implications for paleoceanographic proxies, in: Biomineralization, edited by: Dove, P. M., DeYoreo, J. J., and Weiner, S., Rev. Mineral. Geochem., 115-149, 2003.

Feyling-Hanssen, R. W.: late-Pleistocene foraminifera from the Oslo Fjord Area, South east Norway, Norsk geologisk tidsskrift, 33, 109-150, 2 pls., 1954.
Fontanier, C., Mackensen, A., Jorissen, F. J., Anschutz, P., Licari, L., and Griveaud, C.: Stable oxygen and carbon isotopes of live benthic foraminifera from the Bay of Biscay: Microhabitat impact and seasonal variability, Mar. Micropaleontol., 58, 159-183, doi:10.1016/j.marmicro.2005.09.004, 2006.

Friedman, I. and O'Neil, R.: Compilation of stable isotope fractionation factors of geochemical interest, in: Data of Geochemistry, edited by: Fleischer, M., Geological Survey Professional Paper, US Govt. Printing Office, Washington, DC, 1977.

Grossman, E. L.: Stable isotopes in modern benthic foraminifera: a study of vital effect, J. Foramin. Res., 17, 48-61, 1987.

Hamamoto, H., Yamano, M., and Goto, S.: Heat flow measurement in shallow seas through long-term temperature monitoring, Geophys. Res. Lett., 32, L21311, doi:10.1029/2005g1024138, 2005.

Hintz, C. J., Chandler, G. T., Bernhard, J. M., McCorkle, D. C., Havach, S. M., Blanks, J. K., and Shaw, T. J.: A physicochemically constrained seawater culturing system for production of benthic foraminifera, Limnol. Oceanogr.-Meth., 2, 160-170, 2004.

Ishimura, T., Tsunogai, U., and Gamo, T.: Stable carbon and oxygen isotopic determination of sub-microgram quantities of $\mathrm{CaCO} 3$ to analyze individual foraminiferal shells, Rapid Commun. Mass Sp., 18, 2883-2888, doi:10.1002/rcm.1701, 2004.

Ishimura, T., Tsunogai, U., and Nakagawa, F.: Grain-scale heterogeneities in the stable carbon and oxygen isotopic compositions of the international standard calcite materials (NBS 19, NBS 18, IAEA-CO-1, and IAEA-CO-8), Rapid Commun. Mass Sp., 22, 1925-1932, doi:10.1002/Rcm.3571, 2008.

Kennett, J. P., Cannariato, K. G., Hendy, I. L., and Behl, R. J.: Carbon isotopic evidence for methane hydrate instability during quaternary interstadials, Science, 288, 128-133, 2000.

Kim, S.-T., and O'Neil, J. R.: Equilibrium and nonequilibrium oxygen isotope effects in synthetic carbonates, Geochim. Cosmochim. Ac., 61, 3461-3475, doi:10.1016/s00167037(97)00169-5, 1997.

Kimoto, K., Ishimura, T., Tsunogai, U., Itaki, T., and Ujiie, Y.: The living triserial planktic foraminifer Gallitellia vivans (Cushman): Distribution, stable isotopes, and paleoecological implications, Mar. Micropaleontol., 71, 71-79, doi:10.1016/J.Marmicro.2009.01.006, 2009.

Mackensen, A.: On the use of benthic foraminiferal $13 \mathrm{C}$ in palaeoceanography: constraints from primary proxy relationships, Geol. Soc. London Spec. Publ., 30, 121-133, doi:10.1144/SP303.9, 2008.

Mackensen, A. and Licari, L.: Carbon isotopes of live benthic foraminifera from the South Atlantic Ocean: Sensitivity to bottom water carbonate saturation state and organic matter rain rates, in: The South Atlantic in the Late Quaternary - Reconstruction of Material Budget and Current Systems, edited by: Wefer, G., Mulitza, S., and Rathmeyer, V., Springer-Verlag, Berlin, 623644, 2004.

Mackensen, A., Hubberten, H. W., Bickert, T., Fischer, G., and Futterer, D. K.: The Delta-C-13 in Benthic Foraminiferal Tests of Fontbotia-Wuellerstorfi (Schwager) Relative to the Delta-C-13 of Dissolved Inorganic Carbon in Southern-Ocean Deep-Water - Implications for Glacial Ocean Circulation Models, Paleoceanography, 8, 587-610, 1993.

Martin, J. B., Day, S. A., Rathburn, A. E., Perez, M. E., Mahn, C., and Gieskes, J.: Relationships between the stable iso- 
topic signatures of living and fossil foraminifera in Monterey Bay, California, Geochem. Geophy. Geosyst., 5, Q04004, doi:10.1029/2003GC000629, 2004.

Martin, J. B., Bernhard, J. M., Curtis, J., and Rathburn, A. E.: Combined carbonate carbon isotopic and cellular ultrastructural studies of individual benthic foraminifera: Method description, Paleoceanography, 25, PA2211, doi:10.1029/2009PA001846, 2010.

Matsunaga, H. and Tanaka, T.: CTD hydrocast and water sampling, in: R/V Mirai MR06-04 Cruise Report, edited by: Harada, N., Japan Marine Science and Technology Center, Yokosuka City, Japan, 93-102, 2006.

McCorkle, D. C., Keigwin, L. D., Corliss, B. H., and Emerson, S. R.: The influence of microhabitats on the carbon isotopic composition of deep-sea benthic foraminifera., Paleoceanography, 5 , 161-185, 1990.

McCorkle, D. C., Corliss, B. H., and Farnham, C. A.: Vertical distributions and stable isotopic compositions of live (stained) benthic foraminifera from the North Carolina and California continental margins, Deep-Sea Res. Pt. I, 44, 983-1024, 1997.

McCorkle, D. C., Bernhard, J. M., Hintz, C. J., Blanks, J. K., Chandler, G. T., and Shaw, T. J.: The carbon and oxygen stable isotopic composition of cultured benthic foraminifera, Geol. Soc. London Spec. Publ., 303, 135-154, doi:10.1144/SP303.10, 2008.

McCulloch, I.: Quantitative Observations on Recent Foraminiferal Tests, with Emphasis on the Eastern Pacific, Parts I-III, vi+1078p., 11 tabs., pls. 49-248, Univ. Southern California, Los Angels, 1977.

McCulloch, I.: Quantitative Observations on Recent Foraminiferal Tests, Part IV, with Emphasis on the Allan Hancock AtlanticExpedition Collections, 217 pp., 72 pls., Univ. Southern California, Los Angels, 1981.

Miyajima, T., Yamada, Y., Hanba, Y. T., Yoshii, K., Koitabashi, T., and Wada, E.: Determining the stable isotope ratio of total dissolved inorganic carbon in lake water by GC/C/IRMS, Limnol. Oceanogr., 40, 994-1000, 1995.

Nomaki, H., Heinz, P., Hemleben, C., and Kitazato, H.: Behavior and response of deepsea benthic foraminifera to freshly supplied organic matter: A laboratory feeding experiment in microcosm environments, J. Foramin. Res., 35, 103-113, doi:10.2113/35.2.103, 2005.

Nomura, R.: Cassidulinidae (Foraminiferida) from the uppermost Cenozoic of Japan (Part 1), The Science Reports of the Tohoku University, 2nd ser. (Geology), 53, 1-101, pls. 1-25, 1983a.

Nomura, R.: Cassidulinidae (Foraminiferida) from the uppermost Cenozoic of Japan (Part 2), The Science Reports of the Tohoku University, 2nd ser. (Geology), 54, 1-93, pls. 1-6, 1983b.

Nørvang, A.: Foramtntfera, in: The Zoology of Iceland, vol. 2, pt. 2, Copenhagen and Reykjavik: Ejnar Munksgaard, 1-79, 1945.

Nørvang, A.: Islandiella n.g. and Cassidulina d'Orbigny, Dansk Naturh. Foren. København Vidensk. Meddel., Copenhagen, Denmark, 120, 25-41, pls. 6-8, 1958.

Oba, T.: Paleoceanographic information obtained by the isotopic measurement of Individual Specimens, Proceedings of the First International Conference on Asian Marine Geology, China Ocean Press, Beijing, 169-180, 1988.

Orbigny, A. D.: D' Tableau méthodique de la classe des Céphalopodes, Annales des Sciences Naturelles, ser. 1, 7, 245314, pls. 10-17, 1826.
Parker, W. K., Jones, T. R. and Brady, H. B.: On the nomenclature of the foraminifera. Part. XIV.-The species enumerated by d'Orbigny in the 'Annales des Science Naturelle,' 1826, v. 7., pt. IV. The species founded upon the figures in Soldani's 'Thestaceographia ac Zoophytographia', Annals and Magazine of Natural History, ser. 4, 8, No. 45, 145-179; No. 46, 238-266, pls. 8-12, 1871.

Phleger, F. B.: Foraminifera distribution in some sediment samples from the Canadian and Greenland Arctic, Contribution from the Cushman Foundation for Foraminiferal Research, 3, 80-89, pls. 13-14, 1952.

Pina-Ochoa, E., Hogslund, S., Geslin, E., Cedhagen, T., Revsbech, N. P., Nielsen, L. P., Schweizer, M., Jorissen, F., Rysgaard, S., and Risgaard-Petersen, N.: Widespread occurrence of nitrate storage and denitrification among Foraminifera and Gromiida, P. Natl. Acad. Sci. USA, 107, 1148-1153, doi:10.1073/pnas.0908440107, 2010.

Rathburn, A. E., Corliss, B. H., Tappa, K. D., and Lohmann, K. C.: Comparisons of the ecology and stable isotopic compositions of living (stained) benthic foraminifera from the Sulu and South China seas, Deep-Sea Res. Pt. I , 43, 1617-1646, 1996.

Rathburn, A. E., Peìrez, M. E., Martin, J. B., Day, S. A., Mahn, C., Gieskes, J., Ziebis, W., Williams, D., and Bahls, A.: Relationships between the distribution and stable isotopic composition of living benthic foraminifera and cold methane seep biogeochemistry in Monterey Bay, California. Geochem. Geophys. Geosyst., 4, 1106, doi:10.1029/2003GC000595, 2003.

Reuss, A. E.: Neue Foraminiferen aus den Schichten des österreichischen Tertiärbeckens, K Akad. Wiss. Wien, Math.Naturwiss. Cl, Denkschr., Band 1, 365-390, pls. 46-51, 1850.

Revesz, K. M. and Landwehr, J. M.: delta C-13 and delta O-18 isotopic composition of $\mathrm{CaCO}_{3}$ measured by continuous flow isotope ratio mass spectrometry: statistical evaluation and verification by application to Devils Hole core DH-11 calcite, Rapid Commun. Mass Sp., 16, 2102-2114, doi:10.1002/rcm.833, 2002.

Risgaard-Petersen, N., Langezaal, A. M., Ingvardsen, S., Schmid, M. C., Jetten, M. S. M., Op den Camp, H. J. M., Derksen, J. W. M., Pina-Ochoa, E., Eriksson, S. P., Nielsen, L. P., Revsbech, N. P., Cedhagen, T., and van der Zwaan, G. J.: Evidence for complete denitrification in a benthic foraminifer, Nature, 443, 93-96, doi:10.1038/nature05070, 2006.

Rohling, E. J. and Cooke, S.: Stable oxygen and carbon isotope ratios in foraminiferal carbonate., in: Modern Foraminifera, edited by: SenGupta, B. K., 239-258, 1999.

Schmiedl, G., Pfeilsticker, M., Hemleben, C., and Mackensen, A.: Environmental and biological effects on the stable isotope composition of recent deep-sea benthic foraminifera, from the western Mediterranean Sea, Mar. Micropaleontol., 51, 129-152, doi:10.1016/j.marmicro.2003.10.001, 2004.

Schumacher, S., Jorissen, F. J., Mackensen, A., Gooday, A. J., and Pays, O.: Ontogenetic effects on stable carbon and oxygen isotopes in tests of live (RoseBengal stained) benthic foraminifera from the Pakistan continental margin, Mar. Micropaleontol., 76, 92-103, doi:10.1016/j.marmicro.2010.06.002, 2010.

Shackleton, N. J. and Opdyke, N. D.: Oxygen isotope and paleomagnetic stratigraphy of equatorial Pacific core V28-238: oxygen isotope temperatures and ice volumes on a 105 and 106 year scale., Quaternary Res., 3, 39-55, doi:10.1016/00335894(73)90052-5, 1973. 
Sigman, D. M., Granger, J., DiFiore, P. J., Lehmann, M. M., Ho, R., Cane, G., and van Geen, A.: Coupled nitrogen and oxygen isotope measurements of nitrate along the eastern North Pacific margin, Global Biogeochem. Cy., 19, doi:10.1029/2005gb002458, 2005.

Spero, H. J., Bijma, J., Lea, D. W., and Bemis, B. E.: Effect of seawater carbonate concentration on foraminiferal carbon and oxygen isotopes, Nature, 390, 497-500, 1997.

Toki, T.: Geochemical studies on the origin of methane in crustal fluids using carbon isotopes of methane and carbon dioxide as tracers, Ph. D., Department of Earth and Planetary Sciences, Graduate School of Science, Hokkaodo University, Sapporo, 2004.

Uchida, M., Ohkushi, K., Kimoto, K., Inagaki, F., Ishimura, T., Tsunogai, U., TuZino, T., and Shibata, Y.: Radiocarbon-based carbon source quantification of anomalous isotopic foraminifera in last glacial sediments in the western North Pacific, Geochem. Geophy. Geosyst., 9, Q04N14, doi:10.1029/2006GC001558, 2008.

Velivetskaya, T. A., Ignatiev, A. V., and Gorbarenko, S. A.: Carbon and oxygen isotope microanalysis of carbonate, Rapid Commun. Mass Sp., 23, 2391-2397, doi:10.1002/rcm.3989, 2009.

Zachos, J., Pagani, M., Sloan, L., Thomas, E., and Billups, K.: Trends, rhythms, and aberrations in global climate $65 \mathrm{Ma}$ to present, Science, 292, 686-693, doi:10.1126/science.1059412, 2001.

Zeebe, R. E., Bijma, J., and Wolf-Gladrow, D. A.: A diffusionreaction model of carbon isotope fractionation in foraminifera, Mar. Chem., 64, 199-227, 1999. 